\title{
Investigating The Psychometric Properties of Sport Motivation Scale-II
}

\section{Sporda Güdülenme Ölçeği-II'nin Psikometrik Özelliklerinin İncelenmesi}

\author{
Ali Yıldız ${ }^{1}$, Atahan Altıntaş², Safter Elmas ${ }^{1}$, F. Hülya Aşç1 ${ }^{1}$ \\ ${ }^{1}$ Faculty of Sport Sciences, Marmara University, İstanbul, Turkey \\ ${ }^{2}$ Faculty of Health Sciences, Sport Science Department, Başkent University, Ankara, Turkey
}

\section{A. Ylldiz (iD \\ 0000-0003-2683-1905 \\ A. Altintas \\ 0000-0003-1959-9706 \\ S. Elmas \\ 0000-0002-8519-163X \\ F. H. Așçı \\ 0000-0002-6650-6931}

Geliş Tarihi / Date Received: 27.05.2018

Kabul Tarihi / Date Accepted: 03.08.2018

Yayın Tarihi / Date Published: 08.10.2018

Yazışma Adresi / Corresponding Author:

Ali Yıldız

Marmara Üniversitesi, Spor Bilimleri Fakültesi, İstanbul, Türkiye

E-mail: yildizali7@gmail.com

(C2019 Türkiye Spor Hekimleri Derneği. Tüm hakları saklıdır.

\section{ABSTRACT}

Objective: The purpose of this study was to examine the psychometric properties of Sport Motivation Scale-II (SMS-II) which was developed by Pelletier et al. for Turkish athletes.

Material and Methods: $A$ total of $409\left(\mathrm{M}_{\text {age }}=21.9 \pm 4.3\right)$ athletes consisting of 168 females $\left(M_{\text {age }}=21.2 \pm 3.6\right)$ and 241 males $\left(M_{a g e}=22.4 \pm 4.7\right)$ were accepted to participate in the study. The SMS-II consists of 18 items and six subscales (intrinsic regulation, integrated regulation, identified regulation, introjected regulation, external regulation and amotivated regulation) and is responded on a seven point Likert scale. The confirmatory factor analysis (CFA) was conducted for the construct validity; for concurrent validity, the relationship between SMS-II and Sports Motivation Scale was examined; and for convergent validity, the relationship between SMS-II and Task and Ego Orientation in Sport Questionnaire, the Satisfaction with Life Scale and Subjective Vitality Scale were examined with Pearson product moment correlation. Scale's reliability was tested with Cronbach alfa coefficient.

Results: According to the confirmatory factor analysis results, the values of goodness of fit index of scale with 18 items were $\left(x^{2 / s d}=4.23, \mathrm{IFI}=0.86, \mathrm{TLI}=0.79, \mathrm{CFI}=0.85\right.$, RMSEA $=0.09$ ) and scale with 16 items (without items 3 and 7$)$ were $\left(x^{2 / s d}=2.61, I F I=\right.$ $0.94, \mathrm{TLI}=0.91, \mathrm{CFI}=0.94$ and RMSEA $=0.06$ ). Factor loadings were between 0.43 and 0.84 for the scale with 16 items. Results on the concurrent validity analysis indicated that all subscale scores of SMS-II and all subscale scores of the Sport Motivation Scale were significantly correlated $(p<0.05)$. The results of the analysis for the convergent validity also revealed that there were significant relationships between SMS-II and other scales $(p<0.05)$. The internal consistency figures for the 16 -item model of the scale ranged from 0.44 (Introjected Regulation) to 0.75 (Identified Regulation).

Conclusion: Results indicated that the 16-item Turkish version of SMS-II can be used to determine the motivation level of Turkish athletes.

Keywords: Sports, motivation, scale, validity, reliability

\section{öz}

Amaç: Bu çalışmanın amacı Pelletier ve ark. tarafından geliştirilen "Sporda Güdülenme Ölçeği-II (SGÖ-II)'nin Türk sporcular için psikometrik özelliklerinin test edilmesidir.

Gereç ve Yöntemler: Çalışmaya 168 kadın (Ort ${ }_{\text {yaş }}=21.2 \pm 3.6$ ), 241 erkek sporcu $\left(\right.$ Ort $\left._{\text {yas }}=22.4 \pm 4.7\right)$ olmak üzere toplam 409 (Ort yaş$\left.=21.94 \pm 4.32\right)$ sporcu katıldı. SGÖ-II, 18 madde ve altı alt boyuttan (içsel düzenleme, bütünleşmiş düzenleme, özdeşimle düzenleme, içe atımla düzenleme, dışsal düzenleme ve güdülenmeme) oluşmakta ve yedili Likert tipinde değerlendirilmektedir. Verilerin analizinde; ölçeğin yapı geçerliği için doğrulayıcı faktör analizi (DFA) yapıldı, eş zamanlı geçerlik için Sporda Güdülenme 
Ölçeği ile ilişkisine bakıldı, yakınsak geçerliği için ise Sporda Görev ve Ego Yönelimi Ölçeği, Yaşam Doyum Ölçeği ve Öznel Zindelik Ölçeği ile ilişkisi Pearson Moment Çarpım Korrelasyonu ile test edildi. Ölçeğin güvenilirliği Cronbach alfa güvenilirlik katsayısı hesaplanarak test edildi.

Bulgular: Doğrulayıcı faktör analiz sonuçlarına göre, ölçeğin 18 maddelik modeline ait uyum indeks değerleri $\left(\mathrm{x}^{2 / \mathrm{sd}}=4.23, \mathrm{IFI}=0.86, \mathrm{TLI}=0.79, \mathrm{CFI}=0.85, \mathrm{RMSEA}=0.09\right) ; 16$ maddelik (madde 3 ve 7 olmadan) modele ait uyum indeks değerleri ise $\left(x^{2 / s d}=2.61, I F I=0.94, T L I=0.91, C F I=0.94\right.$ ve $\left.R M S E A=0.06\right)$ olarak bulundu. Elde edilen faktör yükleri 16 maddelik model için 0.43 (içe atımla düzenleme) ile 0.84 (dışsal düzenleme) arasında değişkenlik göstermektedir. Bunun yanı sıra, eş zamanlı geçerlik analizi sonucunda, Sporda Güdülenme Ölçeği-II'nin tüm alt boyut puanları ile Sporda Güdülenme Ölçeğinin tüm alt boyut puanları arasında anlamlı ilişki bulundu $(p<0.05)$. Yakınsak geçerlilik için yapılan analiz sonuçları da Sporda Güdülenme Ölçeği-II ile diğer ölçekler arasında anlamlı ilişki olduğunu ortaya koydu $(p<0.05)$. Ölçeğin 16 maddelik modeli için iç tutarlık değerleri ise 0.44 (içe atımla düzenleme) ile 0.75 (özdeşimle düzenleme) arasında değişmektedir.

Sonuçlar: Bulgular Sporda Güdülenme Ölçeği-Il'nin 16 maddelik Türkçe versiyonunun Türk sporcuların güdülenme düzeylerini belirlemede kullanılabileceğini göstermektedir.

Anahtar Sözcükler: Spor, güdülenme, ölçek, geçerlik, güvenilirlik

Available at: http://journalofsportsmedicine.org and http://dx.doi.org/10.5152/tjsm.2019.114

Cite this article as: Yildiz A, Altintas A, Elmas $S$ et al. Investigating the psychometric properties of Sport Motivation Scale-II. Turk J Sports Med. 2019;54(1):33-44.

\section{GİRIŞ}

Güdü ve güdülenme kavramı psikolojinin en önemli kavramlardan biridir (1). Kavramın çok çeşitli tanımı bulunmaktadır. Temelde güdülenme "davranışın altında yatan neden" anlamına gelir (2). Diğer bir deyişle, güdülenme; organizmayı davranışa iten, bu davranışların şiddet ve enerji düzeyini belirleyen, davranışa yön veren ve devamlılığını sağlayan çeşitli iç ve dış nedenler ve bunların işleyiş mekanizmalarından oluşur (3).

Güdülenmeye dair birçok kuram ortaya atılmıştır. $\mathrm{Bu}$ kuramlardan biri olan "Hür İrade Kuramı" (Self-determination Theory) spora katılımı sürdürmeyi sağlayan içsel ve dışsal güdülenmeyi anlamaya dair kapsamlı bir çerçeve sunması ve farklı güdülerin sporla ilgilenme ve spordan fayda sağlamayla nasıl ilişkili olduğunu göstermesi bakımından öne çıkmaktadır (4).

Hür irade kuramı, insanların etkinliklerinde daha fazla öz-düzenleme, yeterlik ve bütünleşme eğilimlerine sahip canlılar olduğu varsayımı üzerinden kurgulanan bir güdülenme kuramıdır. Kendini gerçekleştirme ve bütünleşme süreci üç temel psikolojik ihtiyaç olan yeterlik, ilişkili olma ve özerkliğin doyurulması ve desteklenmesine dayanır. $\mathrm{Bu}$ temel psikolojik gereksinmeler karşılandığında bireyler devam eden davranış düzenlemelerini doğal bir şekilde içselleştirir ve onlarla bütünleşirler (5).
Bu kuramın bakış açısıyla yapılan çalışmalarda sporda optimal güdülenmenin anlaşılmasında ve desteklenmesinde uygun olduğu kanaati oluşmuştur (6). Spora özgü çalışmalar özerk güdülenmenin uzun süreli spora katılımı yordadığı (7) ve temel psikolojk ihtiyaçların tatminin öznel zindelik, spor doyumu ve istenmeyen fiziksel sonuçları azaltmada etkili olduğunu göstermiştir (8).

Hür İrade Kuramı çerçevesinde güdülenme içsel güdülenme, dişsal güdülenme ve güdülenmeme olmak üzere üç alt boyuttan oluşmaktadır. Bu alt boyutları içselleștirme düzeylerine bağlı olarak bireyler davranışlarını düzenleme yoluna gider. Kuram altı farklı davranış düzenleme stili tanımlamıştır. Bu düzenleme stilleri en özerk olandan en az özerk olana doğru; içsel düzenleme, bütünleşmiş düzenleme, özdeşimle düzenleme, içe atımla düzenleme, dışsal düzenleme ve güdülenmeme olarak sıralanır $(5,9)$.

Hür İrade Kuramı kapsamında geliştirilen İçsel/ Dışsal Güdülenme Ölçeği ve İçsel Güdülenme Envanteri gibi ölçüm araçları kuram içinde tanımlanan güdülenme türlerinin tamamını ölçmede yetersiz kalmışlardır (4). Kuramın bir bütünlük içerisinde güdülenme türlerini en özerk olandan en az özerk olana doğru tanımlanmasından esinlenerek Pelletier ve ark. Sporda Güdülenme Ölçeğini geliştirmişlerdir 
(10). Toplamda 28 madde ve yedi alt boyuttan (bilmek için içsel güdülenme, başarmak için içsel güdülenme, deneyim yaşamak için içsel güdülenme, dışsal düzenleme, içe atımla düzenleme, özdeşimle düzenleme ve güdülenmeme) oluşan ölçek sporda güdülenmeyi ölçmede uzun yıllar etkin olarak kullanılmıştır ve hala kullanılmaktadır (4). Ölçek Bulgarca (11), Türkçe (12) ve İspanyolca (13) gibi farklı dillere çevrilerek geçerliği sınanmıştır. Ayrıca farklı popülasyonlarda test edilen ölçeğin; kadın ve erkek katılımcilar (14), bireysel ve takım sporcuları (15) için uygun bir ölçek olduğu saptanmıştır.

Sporda Güdülenme Ölçeğinin psikometrik özellikleri son yıllarda sorgulanmaya başlamıștır. Mallett, Kawabata, Newcombe, Otero-Forero ve Jackson (16) ölçeğin bütünleşmiş düzenlemeyi de ölçebilmesi için revize edilebileceğini, aksi takdirde ölçeğin "Hür İrade Kuramı"nın tanımladığı tüm yaplları içermeyeceği üzerinde durmuşlardır. Ölçeğin uyumluluk indekslerinin düşük oluşu (17), bazı maddelerinin sorunlu oluşu, içsel güdülenmenin tek boyuta indirilmesi gerekliliği, ölçeğin diş geçerlilik sorununun olması, özdeşimle düzenleme ve içsel düzenlemenin bazı maddelerinin çakışması (16) ve son olarak alt ölçeklerin tanımlanmasında ayrıștırıcılığın eksikliği (4) ölçeğin revize edilmesi gerekliliğini doğurmuştur.

Alan yazında farklı araştırmacılar tarafından belirtilen gerekçelerden yola çlkarak Pelletier ve ark. (4) Sporda Güdülenme Ölçeği'ni iki aşamalı bir çalışmayla revize ederek 18 maddelik ve üçer maddeden oluşan altı boyutlu Sporda Güdülenme Ölçeği-II’yi geliștirmișlerdir. Bu yeni ölçeğe hem bütünleșmiș düzenleme boyutu eklenmiş, hem de içsel güdülenme üç boyuttan tek boyuta indirilmiștir.

Sporda Güdülenme Ölçeği'nin Türkçe geçerlik ve güvenilirliği Kazak (12) tarafından yapılmış ve o tarihten beri ülkemizde yapılan araștırmalarda sıklıkla kullanılmıștır. Buna karșın ölçeğe yukarıda getirilen eleştirilerin Türkçe formu için de geçerli olacağı ve bu nedenle bir revizyon gerekeceği düşünülmektedir.
Yukarıda belirtilen alan yazın gerekliliklerine dayanarak bu çalıșmanın amacl, Sporda Güdülenme Ölçeği-II'nin Türkçe formunun geçerlik ve güvenilirliğinin incelenmesidir. $\mathrm{Bu}$ yolla ülkemizde yapılacak spora özgü çalıșmalarda daha güncel, uluslararası alan yazınıyla paralel ve psikometrik açıdan güçlü bir ölçüm aracının adaptasyonu hedeflenmektedir.

\section{GEREÇ ve YÖNTEMLER}

\section{Katılımcılar}

Araştırma grubu, olasılıksız örneklem yöntemlerinden uygun örnekleme yöntemi ile oluşturuldu. Olasılıksız örneklem yöntemi, evreni oluşturan elemanların eşit şansla seçilmeleri olasılığının bulunmadığı veya buna gerek duyulmadığı durumlarda kullanılır. $\mathrm{Bu}$ nedenle uygun örnekleme yöntemi ile araștırma konusu için en uygun kişiler seçildi. Çalışmaya 168 kadın $\left(\right.$ Ort $\left._{\text {yas }}=21.2 \pm 3.6\right)$ ve 241 erkek $\left(\right.$ Ort $\left._{\text {yaş }}=22.4 \pm 4.7\right)$ olmak üzere toplam 409 $\left(\right.$ Ort $\left._{\text {yaş }}=21.9 \pm 4.3\right)$ sporcu katıldl, eksik doldurulan anketler çalışmadan çıkarıldı. Ölçeğin yapı geçerliliği 409 kişi üzerinde test edildi. Eş zaman ve yakınsak geçerlilik ise tüm katılımcılardan gönüllü olan 124 kişiye Sporda Güdülenme Ölçeği, Sporda Görev ve Ego Yönelimi Ölçeği, Yaşam Doyum Ölçeği ve Öznel Zindelik Ölçeği uygulanarak test edildi. Tüm katılımcıların haftalık antrenman sıklığı ortalamaları 5.08 (SS=1.59), spora katılım sürelerinin ortalaması 110.1 (SS=59.5) aydır. Farklı 33 spor branşından (futbol, basketbol, voleybol, yüzme, yelken, kayak, korfbol, güreş, boks gibi) sporcuları kapsayan çalışmada; katılımcıların \%22.7'si bölgesel lig, \%12.5'i 2. lig, \%13.9'u 1. lig, \%20.0'si süper lig ve $\% 30.8$ 'i milli takım düzeyinde spor yapmakta idi.

\section{Veri Toplama Araçları}

Araștırmada Sporda Güdülenme Ölçeği-II'nin yanı sıra, ölçüt bağıntılı ve yakınsak geçerlilik için Sporda Güdülenme Ölçeği, Sporda Görev ve Ego Yönelimi Ölçeği, Yaşam Doyum Ölçeği ve Öznel Zindelik Ölçeği kullanıldı. 


\section{Kişisel Bilgi Formu}

Altı maddeden oluşan kişisel bilgi formu katılımcıların cinsiyeti, yaşı, spor branşları, spora katılım süreleri, antrenman sıklıkları, spora katılım düzeylerine ilişkin bilgileri toplamak amacıyla araștırmacılar tarafından hazırlandı.

\section{Sporda Güdülenme ölçeği-II (SGÖ-II)}

Pelletier ve ark. (4) tarafından geliştirilen Sporda Güdülenme Ölçeği-II, 18 maddeden oluşmaktadır. İçsel güdülenme, bütünleşmiş düzenleme, özdeşimle düzenleme, içe atımla düzenleme, dışsal düzenleme ve güdülenmeme olmak üzere altı alt boyuttan ve üçer maddeden oluşmaktadır. Ölçek 7'li Likert tipi ölçek kullanılarak değerlendirilmektedir. Buna göre, "1" hiç uymuyor; "7" tamamen uyuyor anlamına gelir. Alt ölçeklerin güvenilirlik alfa değerleri .70 ile .88 arasında değișmektedir (4). Geçerlik ve güvenilirlik çalışması için ölçeği geliştiren araştırmacılarla elektronik posta yoluyla temasa geçildi ve kullanım izni alındı.

\section{Sporda Güdülenme Ölçeği (SGÖ)}

Kazak (12) tarafından Türkçe'ye uyarlanan Sporda Güdülenme Ölçeği, 28 madde ve altı alt boyuttan (Bilmek ve başarmak, uyaran yaşama, dışsal düzenleme, içe atım, özdeşim ve güdülenmeme) oluşmaktadır. Ölçek 7'li Likert tipi ölçek kullanılarak değerlendirilmektedir. Orjinal ölçek yedi boyutlu olsa da, Türkçe uyarlamasında yapılan temel bileșenler faktör analizi sonucunda "Bilmek için içsel güdülenme" ve "Başarmak için içsel güdülenme" boyutları tek boyuta dönüşmüștür. Türkçe'ye uyarlanan alt boyutlarının Cronbach alfa iç tutarlılık katsayıları .70 - .88 arasında değişmektedir (12).

\section{Sporda Görev ve Ego Yönelimi Ölçeği (SGEYÖ)}

Duda (18) tarafından geliştirilen ve Toros (19) tarafından Türkçe'ye uyarlanan Sporda Görev ve Ego Yönelimi Ölçeği, 13 madde ve iki alt boyuttan (Görev yönelimli hedefler ve ego yönelimli hedefler) oluşmaktadır. Ölçek 5'li Likert tipi ölçek kullanılarak değerlendirilmektedir.
Türkçe'ye uyarlanan alt boyutlarının Cronbach alfa iç tutarlılık katsayıları .87 ve .85 'tir (19).

\section{Yaşam Doyumu Ölçeği (YDö)}

Diener ve ark. (20) tarafından geliştirilen, Dağlı ve Baysal (21) tarafından Türkçe'ye uyarlanan Yaşam Doyumu Ölçeği, beş madde ve tek boyuttan oluşmaktadır. Ölçek 5'li Likert tipi ölçek kullanılarak değerlendirilmektedir. Ölçeğin Türkçe formunun Cronbach alfa iç tutarlılık katsayısı .88'dir (21).

\section{Öznel Zindelik Ölçeği (ÖZÖ)}

Ryan ve Frederick (22) tarafından geliştirilen, Uysal ve ark. (23) tarafından Türkçe'ye uyarlanan Öznel Zindelik Ölçeği, yedi madde ve tek boyuttan oluşmaktadır. Ölçek 7'li Likert tipi ölçek kullanılarak değerlendirilmekte ve ölçeğin ikinci maddesi ters kodlanmaktadır. Ölçeğin Türkçe formunun Cronbach alfa iç tutarlılık katsayısı .84'tür (23).

\section{Çeviri Aşaması}

Sporda Güdülenme Ölçeği II'nin (SGÖ-II) çeviri aşaması için Brislin (24) tarafından çeviri-geri çeviri yöntemi için önerilen standart işlem yolu izlendi. Ölçeğin İngilizce orijinalini, akademik İngilizce eğitim görmüş iki araştırmacı Türkçeye çevirmiştir. Türkçe ölçekteki maddelerden aynı çeviriye sahip olanlar belirlenmiștir. Aynı çeviriye sahip maddeler ve farklı çeviriye sahip maddelerin her birinin orijinal hali ve çevrilmiş şekli akademik İngilizce eğitim almış üç farklı yargıcıya gönderilerek en uygun maddeleri seçmeleri ya da kendi alternatiflerini yazmaları istenmiştir. Elde edilen veriler karşılaştırılarak en uygun çeviriler seçilmiştir. Çevirisi tamamlanan ölçek İngilizce alanında uzman iki kişi tarafından tekrar İngilizceye çevrilmiştir. Geri çevirisi yapılan ölçek maddeleri, orijinal ölçek maddeleri ile karşılaștırılarak farklılık ve hatalar belirlenmiştir. İngilizce çeviriler, orijinal ölçekle karşılaştırılıp birbirine en yakın çeviriler seçilerek Türkçe ölçeğin son şekli oluşturulmuştur. 


\section{Verilerin Toplanması}

Kişisel bilgi formuyla birlikte diğer ölçekler araştırma katılımcılarına antrenman öncesi veya sonrasında belirli bir süre gözetmeksizin yüz yüze uygulandı. Uygulama için bir zaman sinırlaması konulmadı, uygulama öncesinde gerekli bilgilendirmeler yapıldı. Uygulama öncesinde tüm katılımcılardan Bilgilendirilmiş Onam Formu alındı.

\section{Verilerin Analizi}

Pelletier ve arkadaşları tarafından geliştirilen (4) Sporda Güdülenme Ölçeği-II'nin özgün faktör yapısı doğrulayıcı faktör analizi ile sinandı. Verilerin analizinde; ölçeğin yapı geçerliliği için doğrulayıcı faktör analizi (DFA) yapıldı, eş zamanlı geçerlilik için Sporda Güdülenme Ölçeği ile ilişskisine Pearson Moment Çarpım Korrelasyonu ile bakıldı, yakınsak geçerlilik için ise Sporda Görev ve Ego Yönelimi Ölçeği, Yaşam Doyum Ölçeği ve Öznel Zindelik Ölçeği ile ilişkisi yine Pearson Moment Çarpım Korrelasyonu ile test edildi. DFA'da esas alınan uyum indeksleri, ki-kare/serbestlik derecesi $\left(\chi^{2} / \mathrm{sd}\right)$, ortalama hata karekök yaklaşımı [Root Mean Square Error Approximation (RMSEA)], Tucker-Lewis indeksi [Tucker-Lewis Index (TLI)], arttırmalı uyum indeksi [Incremental Fit Index (IFI)], karşılaştırmalı uyum indeksi [Comparative Fit Index (CFI)]'dir.

Ki-kare/sd oranının 5.0'ten küçük olması modelin uyumunun kabul edilebilir olduğunu gösterir (25). RMSEA değerinin 0.05 'ten küçük olması mükemmel uyumu, 0-0.05 aralığı iyi uyumu, 0.05-0.10 aralığı ise kabul edilebilir uyumu göstermektedir. CFI değerinde 0.97-1.00 aralığ iyi uyumu, 0.90-0.95 kabul edilebilir uyumu; IFI ve TLI değerlerinde ise 0.90-0.95 aralığının kabul edilebilir uyumu işaret ettiği belirtilmektedir $(26,27)$. Eş zamanlı geçerlilik, aynı yapıyı ölçen yeni bir ölçüm aracı ile geçerliliği kanıtlanmış bir ölçüm aracı arasında tutarlı ilişki varlığıyla sağlanır (28). Bu amaçla Sporda Güdülenme
Ölçeği-II ile Sporda Güdülenme Ölçeği arasında pozitif ilişki beklenmektedir. Yapı geçerliliği (yakınsak geçerlilik-convergent validity) ise yeni geliştirilen bir ölçüm aracı ile kriter olarak kullanılan ve teorik olarak ilişkili olduğu bilinen ölçüm araçları arasında anlamlı ilişki olmasıyla sağlanır (28). Bu amaçla Sporda Güdülenme Ölçeği-II ile Sporda Görev ve Ego Yönelimi Ölçeği, Yaşam Doyum Ölçeği ve Öznel Zindelik Ölçeği arasında pozitif ilişki beklenmektedir. Yapı geçerliliği için kullanılan ölçekler, Hür İrade Kuramı'nın ilişkili olduğunu belirttiği özerklik, yaşam doyumu ve zindelik gibi olumlu yaşam çıktılarından hareketle belirlenmiştir $(7,8)$. Envanterin güvenirliğinin sınanmasında, Croncbach alfa iç tutarlık katsayıları hesaplandı. Eş zamanlı geçerlilik, yapı geçerliliği ve güvenilirlik analizi için SPSS 21, doğrulayıcı faktör analizi için AMOS 21 programları kullanıldı.

\section{BULGULAR}

\section{Doğrulayıcı Faktör Analizi}

Özgün envanterde belirtilen altı faktörlü model için uyum indeks değerleri hesaplanan Sporda Güdülenme Ölçeği-II'ye ait modeller aşağıda sunulmaktadır (Tablo 1).

Yapı geçerliliğine ilişkin bulgulara göre orijinal ölçeğin "içsel düzenleme" alt boyutunda yer alan 3. madde (0.34) ile "içe atımla düzenleme" alt boyutunda yer alan 7 . madde (0.24) düşük faktör yükleri ve ölçeğin düşük uyum indeks değerleri nedeniyle modelden çıkarıldı. Sonrasında yapılan analizde 16 maddelik ölçeğin uyum indeks değerlerinin ve faktör yüklerinin uygun olduğu görüldü. Ölçeğin 16 maddelik modeli incelendiğinde, uyum iyiliği indeks değerlerinin iyi ve kabul edilebilir düzeylerde olduğu ve orijinal ölçekteki gibi altı faktörlü yapının desteklendiği görülmektedir. Doğrulayıcı faktör analizine göre ölçeğin elde edilen faktör yükleri Şekil 1'de gösterilmektedir. 
Tablo 1. Sporda Güdülenme Ölçeği-II 18 ve 16 maddelik modellerine ilişkin uyum indeks değerleri

\begin{tabular}{|c|c|c|c|c|c|}
\hline Uyum indeks değerleri & $\chi 2 / s d$ & CFI & IFI & TLI & RMSEA \\
\hline $\begin{array}{l}\text { Sporda Güdülenme Ölçeği-II } \\
\text { (18 madde) }\end{array}$ & 4.23 & 0.85 & 0.86 & 0.79 & 0.09 \\
\hline $\begin{array}{l}\text { Sporda Güdülenme Ölçeği-II } \\
\text { (16 madde) }\end{array}$ & 2.61 & 0.94 & 0.94 & 0.91 & 0.06 \\
\hline
\end{tabular}

x²/sd: Ki-kare/serbestlik derecesi, CFI: karşılaștırmalı uyum indeksi, IFI: arttırmalı uyum indeksi, TLI: Tucker-Lewis indeksi, RMSEA: yaklaşık hataların ortalama karekökü

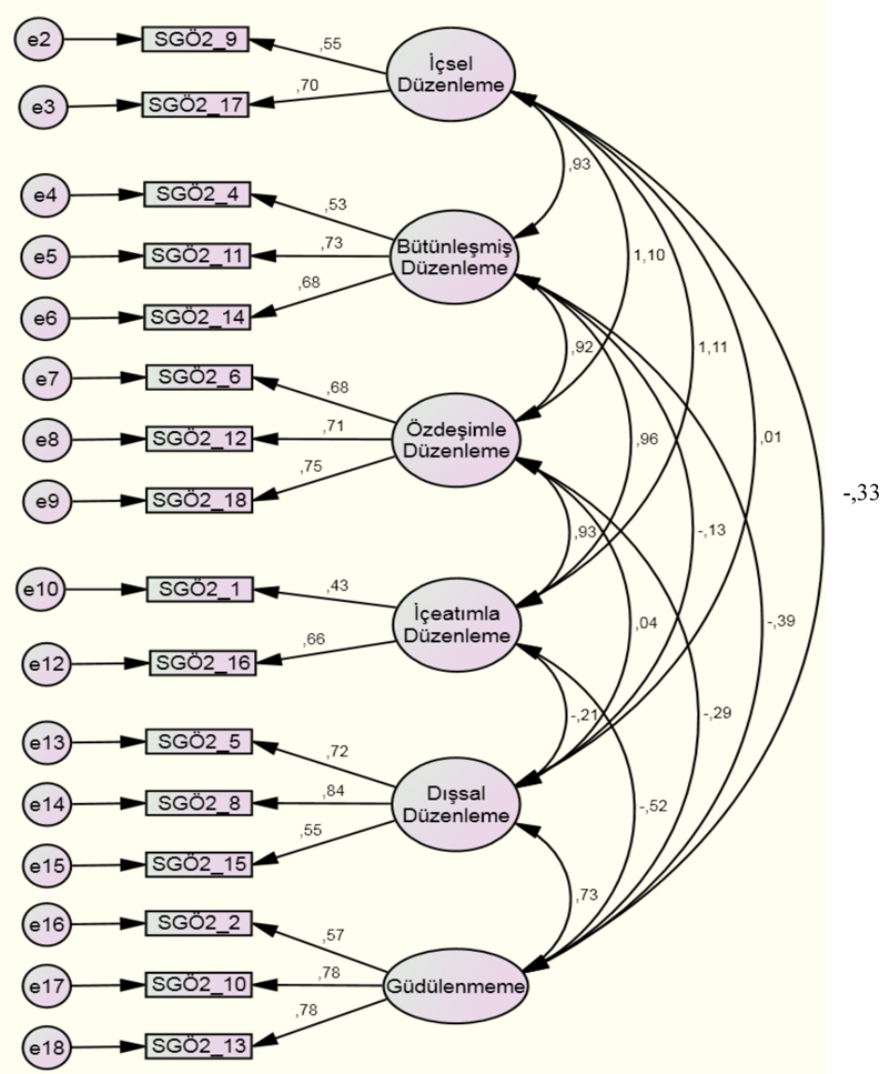

Şekil 1. Sporda Güdülenme Ölçeği II'nin altı faktörlü yapısı

Elde edilen bulgulara göre sporda güdülenme ölçeği için "içsel düzenleme" alt boyutunun faktör yükleri 0.55-0.70, "bütünleşmiş düzenleme" alt boyutunun faktör yükleri 0.53-0.73, "özdeșimle düzenleme" alt boyutunun faktör yükleri 0.68-0.75, "içe atımla düzenleme" alt boyutunun faktör yükleri 0.43-0.66, "dışsal düzenleme" alt boyutunun faktör yükleri 0.55-0.84, "güdülenmeme" alt boyutunun faktör yükleri ise 0.57-0.78 arasında değiști.

\section{Eş Zamanlı Geçerlik Analizi}

Eşzamanlı geçerliliği belirlemek için Sporda Güdülenme Ölçeği-II'nin (4) ve Sporda Güdülenme Ölçeği (10) alt boyut puanları arasındaki korelasyon incelendi (Tablo 2). 
Tablo 2. Sporda Güdülenme Ölçeği II ile Sporda Güdülenme Ölçeği arasındaki ilişkiler

\begin{tabular}{lcccccc}
\hline & $\begin{array}{c}\text { Bilmek ve } \\
\text { başarmak }\end{array}$ & $\begin{array}{c}\text { Uyaran } \\
\text { yaşama }\end{array}$ & $\begin{array}{c}\text { Dişsal } \\
\text { düzenleme }\end{array}$ & $\begin{array}{c}\text { Icçe } \\
\text { atım }\end{array}$ & Özdeşim & Güdülenmeme \\
\hline İçsel düzenleme & $0.61^{* *}$ & $0.43^{* *}$ & -0.00 & $0.45^{* *}$ & $0.36^{* *}$ & -0.12 \\
Bütünleşmiş düzenleme & $0.43^{* *}$ & $0.34^{* *}$ & -0.03 & $0.29^{* *}$ & $0.20^{*}$ & $-0.27^{* *}$ \\
Özdeşimle düzenleme & $0.53^{* *}$ & $0.45^{* *}$ & -0.00 & $0.35^{* *}$ & $0.29^{* *}$ & $-0.28^{* *}$ \\
\hline İçe atımla düzenleme & $0.36^{* *}$ & $0.30^{* *}$ & 0.16 & $0.47^{* *}$ & $0.29^{* *}$ & -0.12 \\
Dişsal düzenleme & $0.23^{*}$ & 0.15 & $0.51^{* *}$ & $0.24^{* *}$ & $0.32^{* *}$ & $0.64^{* *}$ \\
\hline Güdülenmeme & -0.04 & -0.12 & $.40^{* *}$ & -0.03 & $0.20^{*}$ & $0.80^{* *}$ \\
\hline
\end{tabular}

$*$ : $<<0.05 ; * *: p<0.01$

Analizler, içsel düzenleme ile bilmek ve başarmak $(\mathrm{r}=0.61, \mathrm{p}<0.01)$ arasında istatistiksel olarak anlamlı ve pozitif ilișki varlı̆̆ını göstermektedir. Benzer bir şekilde, bütünleşmiş düzenleme ile uyaran yaşama $(\mathrm{r}=0.34, \mathrm{p}<0.01)$, arasında da anlamlı ve pozitif ilişki olduğu bulundu. Ayrıca, özdeşimle düzenleme alt boyutu ile özdeşim $(\mathrm{r}=0.29, \mathrm{p}<0.01)$, içe atımla düzenleme alt boyutu ile içe atım ( $\mathrm{r}=0.47, \mathrm{p}<0.01)$, dışsal düzenleme alt boyutu ile dışsal düzenleme $(\mathrm{r}=0.51, \mathrm{p}<0.01)$, güdülenmeme alt boyutu ile de güdülenmeme $(\mathrm{r}=0.80, \mathrm{p}<0.01)$ arasında anlamlı ve pozitif ilișki varlığı ortaya konuldu. Bașka bir deyișle, analiz sonuçları her iki ölçekteki eş değer alt boyutlar arasında pozitif bir ilişki olduğunu gösterdi.

Ölçeğin yakınsak geçerliliğini belirlemek amacıyla, Sporda Güdülenme Ölçeği-II'nin alt boyut puanları ile Görev-Ego Yönelimi, Öznel Zindelik ve Yaşam Doyumu Ölçeklerinden elde edilen puanlar arasındaki ilişki incelendi (Tablo 3).

Tablo 3. Sporda Güdülenme Ölçeği-II ile Görev-Ego Yönelimi, Öznel Zindelik ve Yaşam Doyumu ölçekleri arasındaki ilişkiler

\begin{tabular}{lcccc}
\hline & Görev yönelimi & Ego yönelimi & Öznel zindelik & Yaşam doyumu \\
\hline İçsel düzenleme & $0.37^{* *}$ & $0.35^{* *}$ & $0.31^{* *}$ & $0.38^{* *}$ \\
Bütünleşmiş düzenleme & $0.38^{* *}$ & 0.13 & $0.31^{* *}$ & $0.25^{* *}$ \\
Özdeşimle düzenleme & $0.33^{* *}$ & $0.21^{*}$ & $0.20^{*}$ & $0.30^{* *}$ \\
İçe atımla düzenleme & $0.23^{*}$ & $0.28^{* *}$ & $0.18^{*}$ & $0.18^{*}$ \\
Dişsal düzenleme & 0.03 & $0.32^{* *}$ & -0.02 & $0.20^{*}$ \\
Güdülenmeme & 0.01 & $0.18^{*}$ & -0.15 & 0.06 \\
\hline
\end{tabular}

${ }^{*} \mathrm{p}<0.05 ;{ }^{* *} \mathrm{p}<0.01$

Elde edilen bulgular, Sporda Güdülenme ÖlçeğiII'nin içsel düzenleme, bütünleșmiș düzenleme, özdeșimle düzenleme ve içe atımla düzenleme alt boyut puanları ile görev yönelimi, öznel zindelik ve yaşam doyumu arasında anlamlı pozitif ilişki olduğunu gösterdi $(p<0.05)$. Diğer yandan; içsel düzenleme, özdeşimle düzenleme, içe atımla düzenleme, dıșsal düzenleme ve güdülenmeme alt boyut puanları ile ego yönelimi arasında anlamlı pozitif ilişki saptandı $(\mathrm{p}<0.05)$. Analiz, dişsal düzenleme alt boyutu ile yaşam doyumu arasında anlamlı pozitif ilişkiyi gösterdi.

\section{Envanterin Güvenilirliğine İlişkin Bulgular}

Envanterin güvenilirliğini belirlemek amacıyla Cronbach alfa iç tutarlık katsayıları hesaplandı. Faktör analizi sonrası elde edilen altı alt boyut için Cronbach alfa iç tutarlık katsayıları Tablo 4'te sunulmaktadir.

Alt boyutlar için elde edilen iç tutarlık katsayı değerleri 0.44 (içe atımla düzenleme) ile 0.75 (özdeșimle düzenleme-güdülenmeme) arasında değișkenlik göstermektedir. 
Tablo 4. Cronbach alfa iç tutarlık katsayıları

\begin{tabular}{lcc}
\hline Alt boyutlar & $\boldsymbol{\alpha}$ & Maddeler \\
\hline İçsel düzenleme & 0.55 & 9,17 \\
Bütünleşmiş düzenleme & 0.68 & $4,11,14$ \\
Özdeşimle düzenleme & 0.75 & $6,12,18$ \\
\hline İçeatımla düzenleme & 0.44 & 1,16 \\
Dişsal düzenleme & 0.73 & $5,8,15$ \\
Güdülenmeme & 0.75 & $2,10,13$ \\
\hline
\end{tabular}

\section{TARTIŞMA}

$\mathrm{Bu}$ çalışma, Pelletier ve ark. (4) tarafından geliștirilen "Sporda Güdülenme Ölçeği II"'nin Türkçe versiyonunun psikometrik özelliklerinin belirlenmesi amacı ile yapıldı.

Analizler ölçeğin 16 maddelik formunun geçerli ve güvenilir olduğunu ortaya koydu. Başka bir deyişle, yapı geçerliliğine ilişkin DFA bulguları orijinal ölçeğin altı faktör yapısı ile tutarlı olmakla birlikte, içsel düzenleme alt boyutunda yer alan 3. madde ("Ne kadar gelișebileceğimi öğrenmek çok ilginç geldiği için") ile içe atımla düzenleme alt boyutunda yer alan 7. madde ("Spor yapmadı̆̆ım zaman kendimi değerli hissetmeyeceğim için") düşük faktör yükleri ve ölçeğin düşük uyum indeks değerleri nedeniyle modelden çıkartıldı.

Doğrulayıcı faktör analizi sonrası 16 maddelik sporda güdülenme ölçeği için elde edilen uyum indeks değerleri, modelin iyi uyum gösterdiğini ortaya koydu. Ki kare değeri örneklem genişliğine duyarlı olduğu için büyük örneklemlerde genellikle anlamlı çıkmaktadır (29). Bu durumda uyum hakkında karar verirken ki kare değerinin serbestlik derecesine oranı kullanılmaktadır. $\mathrm{Bu}$ çalışmada elde edilen oran 2.61 'dir ve 3.0 ve daha düşük oranlar mükemmel uyum olarak kabul edilmektedir (30). Bunun yanı sıra, uyum indeks değerlerinden CFI, IFI ve TLI'nin 0.90'dan büyük olması, RMSEA'nın ise 0.08 'den küçük olması kabul edilebilir olduğuna işaret etmektedir (26). Başka bir deyişle, envanterin yapı geçerliliğini test etmek üzere yapılan doğrulayıcı faktör analiz sonuçları, altı alt boyutlu ve 16 maddeden oluşan ölçeğe ait uyum indekslerinin kabul edilebilir düzeyde olduğunu göstermektedir.

Sporda Güdülenme Ölçeği (10) "içsel güdülenme" boyutunu üç alt boyutta ölçmektedir. Ölçeğe getirilen eleștirilerden biri de bu boyutun hem ölçeğin uzunluğunun kısaltılması, hem de uygulama kolaylığı açısından tek boyuta indirgenmesinin gerekliliğidir (16). Bu çalışmada yapılan DFA sonucunda söz konusu boyut orijinal (SGÖ-II) ölçekte olduğu gibi tek boyuta indirgendi. Buna karşın, orijinalinde üç madde olan içsel düzenleme alt boyutu analiz sonucu ortaya çıkan düşük uyum indeksleri ve faktör yükü nedeniyle üçüncü maddenin çıkarılması sonucu iki maddeye düștü. Literatürde yer alan birçok çalışmada iki maddeli alt boyutların doğrulayıcı faktör analizinde kabul gördüğü yönünde bilgiler yer almaktadır $(31,32)$.

Yazılı kaynaklarda farklı kültürlerde yapılan çalışma sonuçları ile karşılaştırıldığında, bu çalışmaya zıt olarak $\mathrm{Li}$ ve arkadaşları (33) Sporda Güdülenme Ölçeği-II'nin 18 maddelik halinin Çinli sporcular için geçerli ve güvenilir olduğunu belirtmişlerdir. Nascimento Junior ve ark.nın (34) Brezilyalı sporcularda yaptıkları çalışma sonrasında ölçeğin uyum indeks değerleri bizim çalıșmamızda elde edilen değerlere göre daha düşük olmakla birlikte, 18 maddelik formun geçerli ve güvenilir olduğunu bulmuşlardır. 0 çalışmada .38 gibi düşük bir faktör yükü bulunan madde 7 , bizim çalışmamızda düşük aralıkta olması ve modelin uyumuna olumsuz etkisi nedeniyle modelden çlkarıldı. Stenling ve ark. (35) da İsveçli sporcular için ölçeğin geçerli ve güvenilir olduğunu saptamışlardır. Ancak, elde 
ettikleri uyum indeks değerleri ve faktör yükleri buradaki değerlerden daha düşük bulunmuștur.

Çalışmamızda elde edilen değerler farklı kültürlerde yapılan çalışmalardaki uyum indeks değerleri ile benzer olmakla birlikte, kabul edilebilir sayılan düzeylerde olmaması, Türk sporcularda 16 maddelik Sporda Güdülenme Ölçeği-II'nin geçerliliğini destekler niteliktedir. Analizler sonrasında 3. ve 7. maddelerin düşük faktör yüklü bulunması, bu iki maddenin sözel yapısının yeniden ele alınması gerekliliğini ortaya çıkarmaktadır.

Elde edilen sonuçlar gerek eş zamanlı geçerlilik, gerekse yakınsak geçerlilik açısından ölçeğin geçerli olduğunu gösterdi. Eş zamanlı geçerlilik aynı yapıyı ölçen yeni bir ölçüm aracı ile geçerliliği kanıtlanmış bir ölçüm aracı arasında tutarlı bir ilișki varlığıyla sağlanmaktadır. Bu amaçla Sporda Güdülenme Ölçeği-II ile Sporda Güdülenme Ölçeği arasında anlamlı düzeyde ilişki beklendi ve her iki ölçeğin alt boyutları arasında anlamlı düzeyde ilişki ortaya kondu. Özellikle alt boyutların arasinda pozitif ve anlamlı bir ilişki olduğunu gözlendi. Başka bir deyişle, her iki ölçekte aynı yapıyı ölçen kavramlar benzer sonuçları göstermektedir.

Yakınsak geçerlilik yöntemi ile ölçeğin yapı geçerliliği, yeni geliştirilen bir ölçüm aracı ile kriter olarak kullanılan ve teorik olarak ilişkili olduğu bilinen ölçüm araçları arasında anlamlı ilişki olmasıyla sağlanmaktadır. Hür İrade Kuramı, bireylerin bir etkinliğe karşı motive olmaları ve sürdürmeleri ile özerklik, yaşam doyumu ve zindelik gibi olumlu yaşam çıktıları arasında ilişki olduğunu belirtmektedir $(7,8)$. Sözü edilen teorik ilişkiden hareketle, Sporda Güdülenme Ölçeği-II ile sporda görev ve ego yönelimi, yaşam doyumu ve öznel zindelik ölçekleri arasında beklenen anlamlı düzeyde ilișkiler saptandı. Aynı zamanda, dışsal düzenleme ve güdülenmeme alt boyutları ile enerjik ve canlı olmayı ifade eden öznel zindelik arasında negatif ilişki olduğu ortaya kondu. Bu sonuçlara göre, sporcunun dişsal uyaranlar olmadan güdülenmemesinin, hatta hiç güdülenmemesinin bireyin öznel zindeliğini de etkilediğini söyleyebiliriz.
SGÖ-II'nin güvenilirliği Cronbach Alfa katsayıları hesaplanarak test edildi ve ölçeğin 16 maddelik modeli için iç tutarlılık değerleri hesaplandı. Alt boyutlar için elde edilen iç tutarlılık katsayıları 0.44-0.75 arasında değişkenlik gösterdi. Özdamar (36) ölçek iç tutarlılık katsayısına ilişkin ölçütlerin 0.41-0.60 arasında düşük güvenilirlik, 0.61-0.80 arasında orta düzeyde güvenilirlik gösterdiğini belirtmiştir. Nascimento Junior ve ark. (34) SGÖII'nin güvenilirlik değerlerini 0.61-0.78 aralığında bulurlarken, Li ve ark. (33) bu değerleri 0.69-0.78 aralığında saptamışlardır. Literatürde yer alan bu çalışma sonuçları bizim çalışmamızda elde edilenlerle karşılaştırıldığında, içsel düzenleme ve içe atımla düzenleme alt boyutları için daha düşük değerlere ulaştığımız görülmektedir. Diğer alt boyutlara ait güvenirlik değerleri ise benzer bulundu. Şencan'a göre (37) madde sayısının azlığı, güvenilirliğin düşüklügüne neden olmaktadır. Bu noktadan çıkışla, SGÖ-II'nin içsel düzenleme ve içe atımla düzenleme alt boyutlarının düşük güvenilirlik aralığında olmasının madde sayısı azlığından kaynaklandığı söylenebilir.

\section{SONUÇ}

Çalışmanın genel bulguları Sporda Güdülenme Ölçeği-II'nin faktör yapısını ve yapı geçerliliğini destekler niteliktedir. Bulgular temelde elde edilen faktörlerin "Hür İrade Kuramı"nın ortaya attığı tüm güdülenme türlerini kapsaması bakımından tutarlılık göstermektedir. Buna ek olarak, ölçeğin diğer ölçüm araçlarıyla gösterdiği ilişkinin, yine kuramın ilişkili olduğunu iddia ettiği zindelik, yaşam doyumu ve hedef yönelimi kavramları ile tutarlılık gösterdiği ortaya kondu. Tüm bunlardan hareketle, bulgularımız Sporda Güdülenme Ölçeği-II'nin 16 maddelik Türkçe versiyonunun (Ek 1) Türk sporcuların güdülenme düzeylerini belirlemede kullanılabileceğini göstermektedir.

Gelecek çalışmalarda ölçeğin yapı geçerliliğini test edebilmek için MTMM (MultitraitMultimethod Matrix) analizi, madde zorluk düzeylerinin incelenmesi için Rasch analizi gibi farklı istatistiksel yöntemler kullanılabilir. Yetişkin sporculara uyarlanan bu ölçeğin genç sporcular için geçerlik ve güvenilirlik çalışması yapılabilir. 
Elde edilen iç tutarlılık değerleri ölçeğin güvenilirliğini desteklese de, test-tekrar test gibi güvenilirlik çalışmalarının yapılması yararlı olacaktır. Bir ölçeğin ölçüm aracl olarak kullanılışlılığı belki de en iyi uygulama alanındaki işe yararlılığıyla ortaya konur. $\mathrm{Bu}$ nedenle elimizdeki bu ölçek uygulamacılar tarafından sporcuların güdülenme düzeylerinin belirlenmesi ve elde edilecek bilgiden hareketle sporcu güdülenmesi için gerekli müdahaleleri yapmada kullanılabilir. Bunun sporcu güdülenmesine uygun antrenman programları ve çalışmalar düzenlemede yararlı olacağı inancını taşıyoruz.

\section{KAYNAKLAR}

1. Cüceloğlu D. Insan ve Davranışı, 9. Baskı. İstanbul: Remzi Kitabevi; 2008.

2. Guay F, Chanal J, Ratelle CF, et al. Intrinsic, identified, and controlled types of motivation for school subjects in young elementary school children. BrJ Educ Psychol. 2010;80(Pt 4):711-35.

3. Arık İA. Motivasyon ve Heyecana Giriş. İstanbul: Çantay Kitabevi; 1996.

4. Pelletier LG, Rocchi MA, Vallerand RJ, et al. Validation of the revised sport motivation scale (SMS-II). Psychol Sport Exerc. 2013;14:329-41.

5. Deci EL, Ryan RM. Intrinsic Motivation and Selfdetermination in Human Behavior. New York: Plenum; 1985.

6. Vallerand R. Intrinsic and extrinsic motivation in sport and physical activity: A review and a look at the future. In: Tenenbaum G, Eklund RC, editors. Handbook of Sport Psychology, 3rd ed. New York: John Wiley \& Sons; 2007, p. 59-83.

7. Pelletier L, Fortier M, Vallerand, R, et al. Associations among perceived autonomy support, forms of selfregulation, and persistence: A prospective study. Motiv Emot. 2001;25:279-306.

8. Reinboth M, Duda JL, Ntoumanis N. Dimensions of coaching behavior, need satisfaction, and the psychological and physical welfare of young athletes. Motiv Emot. 2004;28:297-313.

9. Deci EL, Ryan RM. The "what" and "why" of goal pursuits: human needs and the self-determination of behavior. Psychol Inq. 2000;11:227-68.

10. Pelletier L, Fortier M, Vallerand RJ, et al. Toward a new measure of intrinsic motivation, extrinsic motivation, and amotivation in sports: The sport motivation scale (SMS). J Sport Exerc Psychol.1995;17:35-54.

11. Chantal Y, Guay F, Dobreva MT. Motivation and elite performance: an exploratory investigation with Bulgarian athletes. Int J Sport Psychol. 1996;27:173-82.
12. Kazak Z. "Sporda Güdülenme Ölçeği -SGÖ-"nin Türk sporcuları için güvenirlik ve geçerlik çalışması. Spor Bilimleri Dergisi. 2004;15:191-206.

13. Núñez J, Martin-Albo J, Navarro JG, et al. Preliminary validation of a Spanish version of the Sport Motivation Scale. Percept Mot Skills. 2006;102:919-30.

14. Li F, Harmer P. Testing the simplex assumption underlying the Sport Motivation Scale: A structural equation modeling analysis. Res Q Exerc Sport. 1996; 67:396-405.

15. Pelletier LG, Sarrazin P. Measurement issues in selfdetermination theory and sport. In: Hagger $M$, Chatzisarantis N, editors. Intrinsic Motivation and SelfDetermination in Exercise and Sport, 1st ed. Champaign, IL: Human Kinetics; 2007, p.143-52.

16. Mallett C, Kawabata M, Newcombe P, et al. Sport motivation scale-6 (SMS-6): A revised six-factor sport motivation scale. Psychol Sport Exerc. 2007;8:600-14.

17. Martens MP, Webber SN. Psychometric properties of the Sport Motivation Scale: An evaluation with college varsity athletes from the US. J Sport Exerc Psychol. 2002; 24:254-70.

18. Duda JL. Relationship between task and ego orientation and the perceived purpose of sport among high school athletes. J Sport Exerc Psychol. 1989;11: 318-35.

19. Toros T. "Sporda Görev ve Ego Yönelim Ölçeği-SGEYÖ-" nin Türk sporcuları için güvenirlik ve geçerlik çalışması. Spor Bilimleri Dergisi. 2004;15:155-66.

20. Diener E, Emmons RA, Larsen RJ, et al. The Satisfaction With Life Scale. J Pers Assess. 1985;49:71-5.

21. Dağlı A, Baysal N. Yaşam Doyumu Ölçeğinin Türkçe’ye uyarlanması: Geçerlik ve güvenirlik çalışması. Elektronik Sosyal Bilimler Dergisi. 2016;15:1250-62.

22. Ryan RM, Frederick C. On energy, personality, and health: subjective vitality as a dynamic reflection of well-being. J Pers. 1997;65:529-65.

23. Uysal R, Sarıçam H, Akın A. Öznel Zindelik Ölçeği Türkçe formunun psikometrik özellikleri. Sosyal ve Beșeri Bilimler Araştırmaları Dergisi. 2014;33:136-46.

24. Brislin RW. The wording and translation of research instruments. In: Lonner WJ, Berry JW, editors. Field Methods in Cross-Cultural Methods, 1st ed. Thousand Oaks, CA: Sage Publications; 1986, p. 137-64.

25. Meydan CH, Şeşen H. Yapısal Eşitlik Modellemesi AMOS Uygulamaları. Ankara: Detay Yayıncılı; 2011.

26. Munro BH. Statistical Methods for Health Care Research, 5th ed. Philadelphia: Lippincott Williams \& Wilkins; 2005, p. 351-76.

27. Schermelleh-Engel $K$, Moosbrugger $H$, Mäüller $H$. Evaluating the fit of structural equation models: Tests of significance and descriptive goodness-of-fit measures. Meth Psychol Res Online. 2003;8:23-74. 
28. Campbell DT, Fiske DW. Convergent and discriminant validation by the multitrait-multimethod matrix. Psychol Bull. 1959;56:81-105.

29. Şimşek ÖF. Yapısal Eşitlik Modellemesine Giriş -Temel Illkeler ve LISREL Uygulamaları. Ankara: Ekinoks Eğitim Danışmanlık; 2007.

30. Sümer N. Yapısal eşitlik modelleri: Temel kavramlar ve örnek uygulamalar. Türk Psikoloji Yazıları. 2000;3(6): 49-74.

31. Pedroso R, Zanetello L, Guimarães L, et al. Confirmatory factor analysis (CFA) of the Crack Use Relapse Scale (CURS). Arch Clin Psychiatry (São Paulo). 2016;43:37-40.

32. Brown TA. Confirmatory Factor Analysis for Applied Research. New York: The Guilford Press; 2006.
33. Li C, Kawabata M, Zhang L. Validity and reliability of the Sport Motivation Scale-II for Chinese athletes. Int J Sport Exerc Psychol. 2016;51-64.

34. Nascimento Junior JRA do, Vissoci JRN, Balbim GM, et al. Cross-cultural adaptation and psychometric properties analysis of the Sport Motivation Scale-II for the Brazilian context. Revista da Educação Física/UEM. 2014;25:44158.

35. Stenling A, Ivarsson A, Johnson $\mathrm{U}$, et al. Bayesian structural equation modeling in sport and exercise psychology. J Sport Exerc Psychol. 2015;37:410-20.

36. Özdamar K. Paket Programlar ile Istatistiksel Veri Analizi 1. Eskişehir: Kaan Kitabevi; 1999.

37. Şençan H. Sosyal ve Davranışsal Ölçümlerde Güvenilirlik ve Geçerlilik. Ankara: Seçkin Yayıncılık; 2005.

Ek 1. Sporda Güdülenme Ölçeği-II'nin 16 maddelik Türkçe versiyonu

Neden spor yapiyorsunuz?

Hiç uymuyor Kısmen uyuyor

Tamamen uyuyor

\begin{tabular}{|c|c|c|c|c|c|c|c|c|}
\hline 1. & $\begin{array}{l}\text { Spor yapmaya vakit ayırmazsam kendimi kötü } \\
\text { hissedeceğim için }\end{array}$ & 1 & 2 & 3 & 4 & 5 & 6 & 7 \\
\hline 2. & $\begin{array}{l}\text { Eskiden spor yapmak için iyi nedenlerim } \\
\text { vardı, ama şimdi spora devam etmeli miyim } \\
\text { diye kendime soruyorum }\end{array}$ & 1 & 2 & 3 & 4 & 5 & 6 & 7 \\
\hline 3. & Spor yapmak kim olduğumu yansıttığı için & 1 & 2 & 3 & 4 & 5 & 6 & 7 \\
\hline 4. & $\begin{array}{l}\text { Spor yapmazsam önemsediğim insanlar bana } \\
\text { kızacağı için }\end{array}$ & 1 & 2 & 3 & 4 & 5 & 6 & 7 \\
\hline 5. & $\begin{array}{l}\text { Önem verdiğim yanlarımı geliştirmenin iyi bir } \\
\text { yolu olarak gördüğgum için }\end{array}$ & 1 & 2 & 3 & 4 & 5 & 6 & 7 \\
\hline 6. & $\begin{array}{l}\text { Spor yapmadığım zaman diğerleri beni } \\
\text { onaylamayacak diye düşündüğüm için }\end{array}$ & 1 & 2 & 3 & 4 & 5 & 6 & 7 \\
\hline 7. & $\begin{array}{l}\text { Yeni performans stratejilerini keşfetmeyi } \\
\text { eğlenceli bulduğum için }\end{array}$ & 1 & 2 & 3 & 4 & 5 & 6 & 7 \\
\hline 8. & $\begin{array}{l}\text { Niçin yaptığımı bilmiyorum artık; uğraşmış } \\
\text { olduğum sporda başarılı olma konusunda } \\
\text { yetersiz olduğum kanısındayım }\end{array}$ & 1 & 2 & 3 & 4 & 5 & 6 & 7 \\
\hline 9. & $\begin{array}{l}\text { Spora katılmak hayatımın ayrılmaz bir parçası } \\
\text { olduğu için }\end{array}$ & 1 & 2 & 3 & 4 & 5 & 6 & 7 \\
\hline 10. & $\begin{array}{l}\text { Bu sporu kendimi geliştirmemin bir yolu } \\
\text { olarak seçtiğim için }\end{array}$ & 1 & 2 & 3 & 4 & 5 & 6 & 7 \\
\hline
\end{tabular}


11. Artık niçin spor yaptığım net değil, sporda yerim olduğunu gerçekten düşünmüyorum 1 2
3

$4 \quad 5 \quad 6 \quad 7$

12. Spor sayesinde en çok önem verdiğim prensiplerime uygun olarak yaşadı̆̆ım için

$\begin{array}{llllllll}1 & 2 & 3 & 4 & 5 & 6 & 7\end{array}$
13. Etrafımdaki insanlar spor yaptığım zaman beni ödüllendirdiği için

1
14. Spor yaptığımda kendimi daha iyi hissettiğim
için
15. Yaptığım spor ile ilgili daha çok şey öğrenmek bana haz verdiği için

1

1

2

1

16. Diğer yönlerimi geliştirmede seçtiğim en iyi

yollardan biri olduğu için

23

$\begin{array}{llll}4 & 5 & 6 & 7\end{array}$

$\begin{array}{llllll}2 & 3 & 4 & 5 & 6 & 7\end{array}$

$\begin{array}{llllll}2 & 3 & 4 & 5 & 6 & 7\end{array}$

